\title{
Synthesis of Pyrazines Using Sugar Derived from Tobacco Cellulose and Hydrolyzed Tobacco F1 Protein as an Amino Acid Source *
}

\author{
by \\ Mehdi Ashraf-Khorassani ${ }^{1}$, William M. Coleman III $^{2}$, Michael F. Dube ${ }^{3}$, and Larry T. Taylor ${ }^{1}$ \\ 1 Department of Chemistry, Virginia Tech, Blacksburg, VA 24061, USA \\ 2 iii Consulting, 210 Jessamine Street, Conway, SC 29526, USA \\ ${ }^{3}$ R.J. Reynolds Tobacco Company, 950 Reynolds Blvd, Winston Salem, NC 27105, USA
}

\section{SUMMARY}

An array of pyrazines have been synthesized using sugars derived from tobacco cellulose (CDS), ammonium hydroxide, and hydrolyzed tobacco $\mathrm{F} 1$ protein as a source of free amino acids (isolated amino acids from F1 hydrolysate, from filtered F1 hydrolysate and from non-filtered F1 hydrolysate). All reactions were performed at $120{ }^{\circ} \mathrm{C}$ for 60 min using a 40-mL Parr reaction vessel. Results showed that the addition of hydrolyzed F1 protein as free amino acid source increased the number of pyrazines with branched alkyl chains (for example, 2-butyl-3-methyl pyrazine) compared to when no amino acids were added. However, using isolated amino acids from hydrolyzed F1 protein versus just hydrolyzed F1 protein (filtered or not filtered) did not make a difference in yield or type of branched pyrazines. When non-filtered hydrolyzed F1 protein was used, the solution was much more viscous and contained suspended solid material when compared to the use of filtered hydrolyzed F1 protein. Addition of threonine (THR) to the reaction mixture did not increase the yield of pyrazines but did slightly shift the distribution of pyrazines toward those with three and four carbons attached. Similar but not identical arrays of pyrazines were obtained when somewhat resembling reaction conditions were applied on a larger reaction scale $(\sim 1.5 \mathrm{~L})$.

A significant $50 \%$-decrease in pyrazine yield was observed when the reaction temperature was reduced from 120 to $100{ }^{\circ} \mathrm{C}$. No noticeable difference in the array of pyrazines from these two reactions was observed. In the majority of cases, the presence of free amino acids resulted in an increase in pyrazine yield coupled with a change in the qualitative array of pyrazines. These results clearly illustrate that sugar prepared from tobacco cellulose (glucose) can be used just like high fructose corn syrup to prepare flavor compounds via Amadori and Maillard reactions. The evidence highlights that hydrolyzed amino acids from F1 tobacco protein can be used via Maillard reactions to produce complementary arrays of pyrazine flavor compounds. [Beitr. Tabakforsch. Int. 28 (2018) 103-111]

\section{ZUSAMMENFASSUNG}

Unter Einsatz von Zuckern, die aus Tabakzellulose gewonnen wurden (CDS) sowie Ammoniumhydroxid und hydrolysiertem Tabakprotein F1 als Quelle freier Aminosäuren (isolierte Aminosäuren aus F1-Hydrolysat, aus gefiltertem F1-Hydrolysat sowie aus nicht gefiltertem F1-Hydrolysat) wurde eine Reihe Pyrazine synthetisiert. Alle Reaktionen wurden für eine Dauer von $60 \mathrm{~min}$ bei $120^{\circ} \mathrm{C}$ unter Einsatz eines 40-mL Parr-Reaktionsbehälters durchgeführt. Die Ergebnisse zeigten, dass die Zugabe von hydrolysiertem Protein F1als Quelle freier Aminosäuren die Anzahl der Pyrazine mit verzweigten Alkylketten (z.B. 2-Butyl-3methylpyrazin) gegenüber keiner Zugabe von Aminosäuren erhöhte. Jedoch ergab sich beim Einsatz von aus hydrolysiertem Protein F1 isolierten Aminosäuren im Vergleich 
zum bloßen Einsatz von hydrolysiertem Protein F1 (gefiltert oder nicht gefiltert) kein Unterschied hinsichtlich Ausbeute oder Typ der verzweigten Pyrazine. Wurde ungefiltertes hydrolysiertes Protein F1 eingesetzt, enthielt die Lösung Schwebstoffe und war sehr viel viskoser, als wenn gefiltertes hydrolysiertes Protein F1 verwendet wurde. Die Zugabe von Threonin zum Reaktionsgemisch erhöhte nicht die Ausbeute an Pyrazinen aber veränderte leicht die Verteilung der Pyrazine zugunsten von Pyrazinen mit drei oder vier Kohlenstoffatomen. Es ergaben sich ähnliche aber nicht identische Pyrazinreihen wenn vergleichbare Reaktionsbedingungen in einem größeren Reaktionsmaßstab $(\sim 1,5 \mathrm{~L})$ angewandt wurden. Wenn die Temperatur von 120 auf $100^{\circ} \mathrm{C}$ verringert wurde, konnte ein signifikanter Rückgang der Pyrazinausbeute um 50\% beobachtet werden. Es wurde kein erkennbarer Unterschied in der Pyrazinreihe aus diesen beiden Reaktionen beobachtet. In den meisten Fällen führte das Vorhandensein von freien Aminosäuren zu einer Zunahme der Pyrazinausbeute gepaart mit einer qualitativen Veränderung der Pyrazinreihe. Diese Ergebnisse zeigen eindeutig, dass Zucker aus Tabakzellulose (Glukose) genauso wie Maissirup (HFCS, High Fructose Corn Syrup) eingesetzt werden kann, um mithilfe der Amadori-Umlagerung und der Maillard-Reaktion Aromaverbindungen herzustellen. Es wird anhand dieser Daten deutlich, dass aus dem Tabakprotein F1 hydrolysierte Aminosäuren eingesetzt werden können, um mittels der Maillard-Reaktion komplementäre Reihen an Pyrazin-Aromaverbindungen herzustellen. [Beitr. Tabakforsch. Int. 28 (2018) 103-111]

\section{RESUME}

Une série de pyrazines fut synthétisée à l'aide de sucres dérivés de la cellulose de tabac (CDS), d'hydroxyde d'ammonium et d'une protéine F1 de tabac hydrolysée en guise de source d'acides aminés libres (acides aminés isolés provenant de l'hydrolysat F1, de l'hydrolysat F1 filtré et de l'hydrolysat $\mathrm{F} 1$ non filtré). Toutes les réactions furent opérées à $120^{\circ} \mathrm{C}$ durant $60 \mathrm{~min}$ dans un réacteur PARR de $40 \mathrm{~mL}$. Les résultats révélèrent que l'ajout d'une protéine F1 hydrolysée en guise de source d'acides aminés libres augmentait le nombre de pyrazines à chaînes d'alkyles ramifiées (par exemple, de la 2-butyl-3-méthyl pyrazine) comparativement à l'absence d'ajout d'acides aminés. Toutefois, l'utilisation d'acides aminés isolés provenant d'une protéine F1 hydrolysée plutôt que seulement une protéine F1 hydrolysée (filtrée ou non) n'influença ni l'obtention ni le type de pyrazines ramifiées. Lors de l'utilisation d'une protéine F1 hydrolysée non-filtrée, la solution s'avéra bien plus visqueuse et contenait des matières solides en suspension contrairement à la solution obtenue grâce à la protéine F1 hydrolysée filtrée. L'ajout de thréonine au mélange réactionnel n'augmenta pas le rendement de pyrazines mais altéra légèrement la répartition des pyrazines vers celles ayant trois et quatre atomes de carbone. Des séries similaires, sans être identiques, de pyrazines furent obtenues lors de l'application de conditions de réaction relativement semblables à une échelle de réaction supérieure, à savoir $\sim 1,5 \mathrm{~L}$. Un écart significatif, à savoir une réduction de $50 \%$ du rendement des pyrazines, fut observé en cas de baisse de la tempé- rature de réaction de 120 à $100{ }^{\circ} \mathrm{C}$. Aucune différence notable dans la série de pyrazines obtenues par ces deux réactions ne fut observée. Dans la majorité des cas, la présence d'acides aminés libres provoqua une augmentation du rendement de pyrazines, associée à un changement dans la série qualitative des pyrazines. Ces résultats illustrent clairement que le sucre préparé à partir de cellulose de tabac (glucose) peut, à l'instar du sirop de maïs à haute teneur en fructose, entrer dans la préparation des composés aromatiques grâce à des réarrangements d'Amadori et des réactions de Maillard. Les preuves révèlent que les acides aminés hydrolysés provenant de la protéine de tabac F1 peuvent être utilisés, grâce aux réactions de Maillard, pour la production de séries complémentaires de composés aromatiques issus de la pyrazine. [Beitr. Tabakforsch. Int. 28 (2018) 103-111]

\section{INTRODUCTION}

Pyrazines can be formed by heating a mixture of sugars with nitrogen sources such as ammonium hydroxide $\left(\mathrm{NH}_{4} \mathrm{OH}\right)$ and amino acids (AA) (1). When sugars and nitrogen sources, such as ammonium hydroxide $\left(\mathrm{NH}_{4} \mathrm{OH}\right)$ and diammonium hydrogen phosphate $\left(\left(\mathrm{NH}_{4}\right)_{2} \mathrm{HPO}_{4}\right)$, are employed in heated reactions, pyrazines are produced via Amadori reaction and when amino acids are involved pyrazines are produced via Maillard reaction. In most cases the structures of the pyrazines formed by Amadori and Maillard reactions are notably different. Using such an approach, pyrazine formation has been studied extensively (2-4). Most of these studies involved ideal pure reagent systems, in which specific sugars, such as glucose, fructose and or rhamnose, amino acids, such as threonine, leucine, isoleucine and alanine, and $\mathrm{NH}_{4} \mathrm{OH}$ were examined for their effects on pyrazine yields and structures. As a result of these studies a considerable knowledge base exists concerning the effects of these different reagent variables as well as reaction conditions on pyrazine formation. It is also known that temperature, time, reagent ratios, and use of ammonium salts as additives, all have significant effects on pyrazine formation (1). Additionally, different amino acids are known to affect the structure of pyrazines formed (1, 4-6). Previously, an optimized method was developed to hydrolyze F1 protein for production of an array of tobacco-derived free amino acids (7). Tobacco F1 protein is considered to be the major protein fraction of the tobacco plant leaf comprising at least $2-5 \%$ by weight for cured leaf that usually has approximately $12 \%$ moisture. The F1 protein in tobacco is ribulose-1,5-biphosphate carboxylase/ oxygenase and is commonly referred to with the abbreviation, RuBisCO. The composition (amino acid array) of this protein has been previously well defined and the types of amino acids therein are very suitable for participation in the Maillard reaction to produce pyrazines (7). Some of these F1 amino acids that participate in Maillard reaction are threonine, valine, alanine, leucine and isoleucine. The latter four of these amino acids are known for their capability for producing Strecker aldehydes that participate in the formation of pyrazines which usually produce pyrazines with alkyl side chains. These bear structures similar to those present in the free amino acid alkyl chains. Thus, these free 
amino acids from $\mathrm{F} 1$ proteins can be envisioned to serve as nitrogen sources in reactions designed to prepare arrays of pyrazines.

In this current study, sugars derived from tobacco cellulose (CDS), hydrolyzed tobacco F1 proteins (isolated and purified free amino acids, filtered and non-filtered hydrolyzed $\mathrm{F} 1$ proteins), and $\mathrm{NH}_{4} \mathrm{OH}$ were used as reagents to produce pyrazines. In all reactions, sugar concentration, $\mathrm{NH}_{4} \mathrm{OH}$ volume, reaction temperature, reaction time, and final reaction volume were kept constant, employing a $40-\mathrm{mL}$ Parr reactor. The yields and structures of the resulting pyrazines formed as functions of these variables were determined. Using the same conditions, reagent amounts and reaction volumes were scaled up to $\sim 1 \mathrm{~L}$ and the pyrazines were isolated.

\section{EXPERIMENTAL}

\section{Materials}

Ammonium hydroxide (28-30\%), $\mathrm{d}_{6}$-methylpyrazine, ethanol, methanol and methylene chloride were obtained from Sigma-Aldrich (St. Louis, MO, USA). F1 protein was obtained from R.J. Reynolds Tobacco Co. (RJR) and hydrolyzed using previously developed optimum conditions (7). High fructose corn syrup (HFCS) was obtained from Ingredion (London, Ontario, Canada) as an aqueous solution containing $\sim 70 \%$ sugar comprised of $\sim 55 \%$ fructose and $45 \%$ glucose. Sugars derived from tobacco cellulose (CDS) were obtained from RJR and were comprised of an aqueous solution of $\sim 70 \%$ glucose. Reversed-phase silica gel $90 \mathrm{C}_{18}$ packing material was obtained from SigmaAldrich. Percent hydrolyzed amino acids in all of our hydrolyzed solutions were determined to be in the range of $50-55 \%$, as previously reported $(3,7)$. All pyrazine synthetic reactions, with one exception, vide infra, were performed in a 40-mL Parr vessel which could handle high pressure and temperature reactions. In each reaction $7.7 \mathrm{~g}$ of CDS or HFCS were mixed with $1.8 \mathrm{~mL}$ of $\mathrm{NH}_{4} \mathrm{OH}$ and then enough hydrolyzed $\mathrm{F} 1$ protein was added to make the mass of free amino acids equal to $0.4 \mathrm{~g}$. For example, when $40 \mathrm{~g}$ of $\mathrm{F} 1$ protein were hydrolyzed in $1 \mathrm{~L}$ solution, the percent amino acids in solution was equal to $50 \%$, which was equal to $20 \mathrm{~g}$ of amino acids in $1 \mathrm{~L}$ solution. In order to use $0.4 \mathrm{~g}$ of amino acids in a reaction, only $20 \mathrm{~mL}$ of the above solution was added to the reaction vessel. If the volume was less than $20 \mathrm{~mL}$, enough $\mathrm{H}_{2} \mathrm{O}$ was added to the solution to adjust the volume to a constant $20 \mathrm{~mL}$. In some of the reactions, no hydrolyzed $\mathrm{F} 1$ protein was used and only $20 \mathrm{~mL}$ of water were added to adjust the volume. After completion of each reaction, the mixture was spiked with $250 \mu \mathrm{g}$ of internal standard $\left(\mathrm{d}_{6}\right.$-methylpyrazine $)$ and pyrazines extracted with $20-30 \mathrm{~mL}$ of dichloromethane. Each pyrazine we quantified against the mass of internal standard added to the extraction solvent. Reagent amounts and reaction volumes were proportionally increased for the reaction at $\sim 1 \mathrm{~L}$ volume.

Different hydrolyzed F1 proteins as sources of amino acids were tested to determine which was better suited (highest yield, desired qualitative distribution) for formation of pyrazines using CDS. These hydrolyzed F1 proteins were:
1. Amino acids from hydrolyzed F1 protein which was filtered after hydrolysis

2. Amino acids from hydrolyzed F1 protein which was not filtered after hydrolysis

3. Amino acids which were isolated using resins after hydrolysis of F1 protein

\section{Instrumentation}

All GC/MS analyses were performed using a $6890 \mathrm{GC}$ equipped with a 5973 Mass Selective detector (MSD) from Agilent (Wilmington, DE, USA). Separations were obtained using a DB-WAXETR capillary column $(30 \mathrm{~m} \times$ $250 \mu \mathrm{m}$ I.D. with a film thickness of $0.25 \mu \mathrm{m}$ ) from J\&W (Wilmington, DE, USA). The following operating parameters were used for each analysis:

$\begin{array}{ll}\text { - Injection port temperature } & 260{ }^{\circ} \mathrm{C} \\ \text { - Purge valve } & 3 \mathrm{~mL} / \mathrm{min} \\ \text { - Purge time } & 1 \mathrm{~min} \\ \text { - Total flow } & 24 \mathrm{~mL} / \mathrm{min} \\ \text { - Constant flow } & 1 \mathrm{~mL} / \mathrm{min} \\ \text { - Injection volume } & 2 \mu \mathrm{L}, \text { split } 1: 20 \\ \text { - Column oven initial temperature } & 50^{\circ} \mathrm{C} \\ \text { - Column oven initial time } & 3 \mathrm{~min} \\ \text { - Column oven ramp rate } & 15^{\circ} \mathrm{C} / \mathrm{min} \\ \text { - Column oven final temperature } & 250^{\circ} \mathrm{C} \\ \text { - Column oven final time } & 1 \mathrm{~min} \\ \text { - MSD transfer line temperature } & 260^{\circ} \mathrm{C}\end{array}$

MS Wiley library was used to identify each pyrazine. For quantitative analysis, pyrazines were quantified using single ion monitoring mode, employing the most intense ion for each specific pyrazine. Each pyrazine was quantified against the mass of internal standard $(250 \mu \mathrm{g})$ added to the extraction solvent. Extracted ions which were used to quantify each pyrazine are listed in Tables 2-4.

\section{RESULTS AND DISCUSSION}

Reaction of HFCS with and without filtered hydrolyzed F1 protein

In the initial part of this study, HFCS was tested as the sugar base for the reactions to see what type of pyrazines were formed with and without amino acids from hydrolyzed $\mathrm{F} 1$ protein. Also, the mass of each pyrazine from each reaction $\left(7.7 \mathrm{~g}\right.$ of $\mathrm{HFCS}+1.8 \mathrm{~mL} \mathrm{NH}_{4} \mathrm{OH}$ with and without $0.4 \mathrm{~g}$ of amino acids from hydrolyzed $\mathrm{F} 1$ protein at $120^{\circ} \mathrm{C}$ for $60 \mathrm{~min}$ ) was determined. Table 1 shows a list of all reactions and their conditions used in this study. Table 2 contains a list of detected pyrazines and their calculated mass based on addition of fixed mass of deuterated 2-methylpyrazine (internal standard) after each reaction (assuming all pyrazines have similar ionization response). It is important to note that values for pyrazine $(\mathrm{m} / \mathrm{z}=80)$ and methylpyrazine $(\mathrm{m} / \mathrm{z}=94)$ do not appear in the Tables. While they were a significant contributor to the pyrazine array in a number of these reactions (Figures 1-3), these pyrazines are generally recognized as having little sensory value coupled with less than optimum physical properties 
Table 1. Reaction conditions and reagent ratios.

\begin{tabular}{|c|c|c|c|c|c|c|c|}
\hline $\begin{array}{l}\text { Reaction } \\
\text { letter }\end{array}$ & $\begin{array}{l}\text { Sugar } \\
\text { source }\end{array}$ & $\begin{array}{l}\text { Sugar } \\
\text { mass (g) }\end{array}$ & $\begin{array}{c}\mathrm{NH}_{4} \mathrm{OH} \\
\mathrm{mL}\end{array}$ & $\begin{array}{c}\text { Amino Acids } \\
\text { AA }\end{array}$ & $\begin{array}{c}\text { Reaction temp. } \\
{ }^{\circ} \mathrm{C}\end{array}$ & $\begin{array}{c}\text { Reaction time } \\
\text { min }\end{array}$ & Special notes \\
\hline A & HFCS & 7.7 & 1.8 & None & 120 & 60 & No mixing \\
\hline B & HFCS & 7.7 & 1.8 & None & 120 & 60 & \\
\hline C & HFCS & 7.7 & 1.8 & None & 120 & 60 & \\
\hline $\mathrm{D}$ & HFCS & 7.7 & 1.8 & $20 \mathrm{~mL}$ of filter $\mathrm{F} 1$ hydrolysate $(1)^{*}$ & 120 & 60 & $0.4 \mathrm{~g}$ free $\mathrm{AA}$ \\
\hline $\mathrm{E}$ & HFCS & 7.7 & 1.8 & $2.5 \mathrm{~mL}$ of purified $\mathrm{AA}(3)$ & 120 & 60 & $0.4 \mathrm{~g}$ free $\mathrm{AA}$ \\
\hline $\mathrm{F}$ & CDS & 7.7 & 1.8 & None & 120 & 60 & \\
\hline G & CDS & 7.7 & 1.8 & $20 \mathrm{~mL}$ of $\mathrm{F} 1$ hydrolysate (1) & 120 & 60 & $0.4 \mathrm{~g}$ free $\mathrm{AA}$ \\
\hline $\mathrm{H}$ & CDS & 7.7 & 1.8 & $2.5 \mathrm{~mL}$ of purified $\mathrm{AA}(3)$ & 120 & 60 & $0.4 \mathrm{~g}$ free $\mathrm{AA}$ \\
\hline I & CDS & 7.7 & 1.8 & $5 \mathrm{~mL}$ of purified AA (3) & 120 & 60 & $0.8 \mathrm{~g}$ free $\mathrm{AA}$ \\
\hline $\mathrm{J}$ & CDS & 7.7 & 1.8 & $20 \mathrm{~mL}$ of unfiltered hydrolysate (2) & 120 & 60 & $0.4 \mathrm{~g}$ free $\mathrm{AA}$ \\
\hline K & CDS & 7.7 & 1.8 & $20 \mathrm{~mL}$ of $\mathrm{F} 1$ filter hydrolysate (1) & 120 & 60 & $0.4 \mathrm{~g}$ free $\mathrm{AA}+0.4 \mathrm{~g}$ of $\mathrm{THR}$ \\
\hline
\end{tabular}

* See Experimental section for the type of F1 hydrolysate was used.

Table 2. Mass of pyrazines formed via reaction of $\mathrm{HFCS}, \mathrm{NH}_{4} \mathrm{OH}$ and amino acids from filtered, unfiltered, and purified hydrolyzed F1 protein.

\begin{tabular}{ll|r|r|r|rrr|r}
\hline $\begin{array}{l}\text { Retention } \\
\text { time }\end{array}$ & \multicolumn{1}{c|}{ Experiment conditions } & $\begin{array}{c}\text { Quantitative } \\
\text { ion }\end{array}$ & $\begin{array}{c}A^{* * *} \\
\text { mass }(\mu \mathrm{g})\end{array}$ & $\begin{array}{c}\mathrm{B}^{*} \\
\text { mass }(\mu \mathrm{g})\end{array}$ & $\begin{array}{c}\mathrm{C}^{*} \\
\text { mass }(\mu \mathrm{g})\end{array}$ & $\begin{array}{c}\mathrm{D}^{*} \\
\text { mass }(\mu \mathrm{g})\end{array}$ & $\begin{array}{c}\mathrm{E}^{* * *} \\
\text { mass }(\mu \mathrm{g})\end{array}$ \\
\hline 5.192 & Pyrazine & 80 & & & & & & \\
5.92 & 2-Methylpyrazine & 94 & & & & & \\
5.92 & 2-Methylpyrazine-d ${ }_{6}$ (int. standard) & 100 & 250.0 & 250.0 & 250.0 & 250.0 & 250.0 \\
6.61 & 2,5-Dimethylpyrazine & 108 & 2590.4 & 2172.6 & 1452.6 & 1454.5 & 1890.9 \\
6.68 & 2,6-Dimethylpyrazine & 108 & 9262.7 & 7980.5 & 4863.5 & 12314.2 & 14030.6 \\
6.72 & 2-Ethylpyrazine & 108 & 511.8 & 396.2 & 195.8 & 414.3 & 474.4 \\
6.88 & 2,3-Dimethylpyrazine & 108 & 1577.8 & 1343.7 & 999.7 & 1429.8 & 1607.7 \\
7.29 & 2-Ethyl 6-methylpyrazine & 122 & 140.3 & 102.9 & 46.7 & 165.4 & 176.9 \\
7.37 & 2-Ethyl 5-methylpyrazine & 122 & 43.3 & 29.9 & 15.4 & 22.9 & 28.9 \\
7.52 & Trimethylpyrazine & 122 & 799.9 & 682.5 & 491.4 & 1011.7 & 1115.1 \\
7.79 & 2-Vinylpyrazine & 106 & 0.0 & 154.3 & 80.8 & 56.5 & 84.6 \\
7.91 & 3-Ethyl-2,5-dimethylpyrazine & 136 & 14.9 & 12.0 & 0.0 & 32.9 & 36.5 \\
8.08 & 5-Ethyl-2,3-dimethylpyrazine & 136 & 16.1 & 11.8 & 0.0 & 34.8 & 39.4 \\
8.22 & Tetramethylpyrazine & 136 & 20.0 & 16.5 & 11.8 & 17.0 & 21.7 \\
8.31 & 2-Ethenyl-6-methylpyrazine & 120 & 41.7 & 31.5 & 16.1 & 26.9 & 33.0 \\
8.42 & 2-Butyl-3-methylpyrazine & 108 & 0.0 & 0.0 & 0.0 & 17.0 & 19.7 \\
9.16 & 3-Methylbutylpyrazine & 94 & 0.0 & 0.0 & 0.0 & 94.9 & 116.4 \\
9.80 & 2,5-Diethyl-3-methylbutylpyrazine & 122 & 0.0 & 0.0 & 0.0 & 53.6 & 60.1 \\
& Total pyrazine mass $(\mu \mathrm{ng})$ & & 15087.2 & 12989.0 & 8192.7 & 17178.5 & 19781.0 \\
\hline
\end{tabular}

*** single reaction, * duplicate reactions

A $\quad 7.7 \mathrm{~g} \mathrm{HFCS}, 1.8 \mathrm{~mL} \mathrm{NH}_{4} \mathrm{OH}$, No AA, $120^{\circ} \mathrm{C}, 60 \mathrm{~min}$ (no mixing)

B $\quad 7.7 \mathrm{~g} \mathrm{HFCS}, 1.8 \mathrm{~mL} \mathrm{NH}_{4} \mathrm{OH}$, No AA, $120^{\circ} \mathrm{C}, 60 \mathrm{~min}$

C $\quad 7.7 \mathrm{~g} \mathrm{HFCS}, 1.8 \mathrm{~mL} \mathrm{NH} \mathrm{HH}_{4} \mathrm{OH}$, $\mathrm{AA}, 100^{\circ} \mathrm{C}, 60 \mathrm{~min}$

D $7.7 \mathrm{~g} \mathrm{HFCS}, 1.8 \mathrm{~mL} \mathrm{NH}_{4} \mathrm{OH}, 20 \mathrm{~mL}$ F1 hydrolysate $(0.4 \mathrm{~g} \mathrm{AA}), 120^{\circ} \mathrm{C}, 60 \mathrm{~min}$

E $\quad 7.7 \mathrm{~g} \mathrm{HFCS}, 1.8 \mathrm{~mL} \mathrm{NH}_{4} \mathrm{OH}, 2.5 \mathrm{~mL}$ purified $\mathrm{AA}(0.4 \mathrm{~g} \mathrm{AA}), 120^{\circ} \mathrm{C}, 60 \mathrm{~min}$

$(8,9)$, and were hence not considered in the overall evaluations of the pyrazines produced as a result of these reactions. Noteworthy was the observation that butyl-substituted pyrazines were detected only in reactions that contained free amino acids from hydrolyzed F1 protein (see Table 2, reaction with and without AA). This influence on pyrazine structure due to the presence of free amino acids in model reactions is consistent with published results. Also, the total mass of pyrazines increased with addition of free amino acids from the hydrolysate. Results showed that at heating to $120^{\circ} \mathrm{C}$ the reaction was more effective in the synthesis of pyrazines than at $100^{\circ} \mathrm{C}$, in accordance with published results (4). In one reaction, the mixture was not stirred (no mixing), see Table 2, with minimal impact on pyrazine yield and qualitative array.

Results showed that the total mass of pyrazines for the nonstirred reaction was higher than for the reaction of those mixed. No clear rationale for this observation was readily apparent, and mixing/stirring was employed for all subsequent reactions. For HFCS, when purified amino acid was 


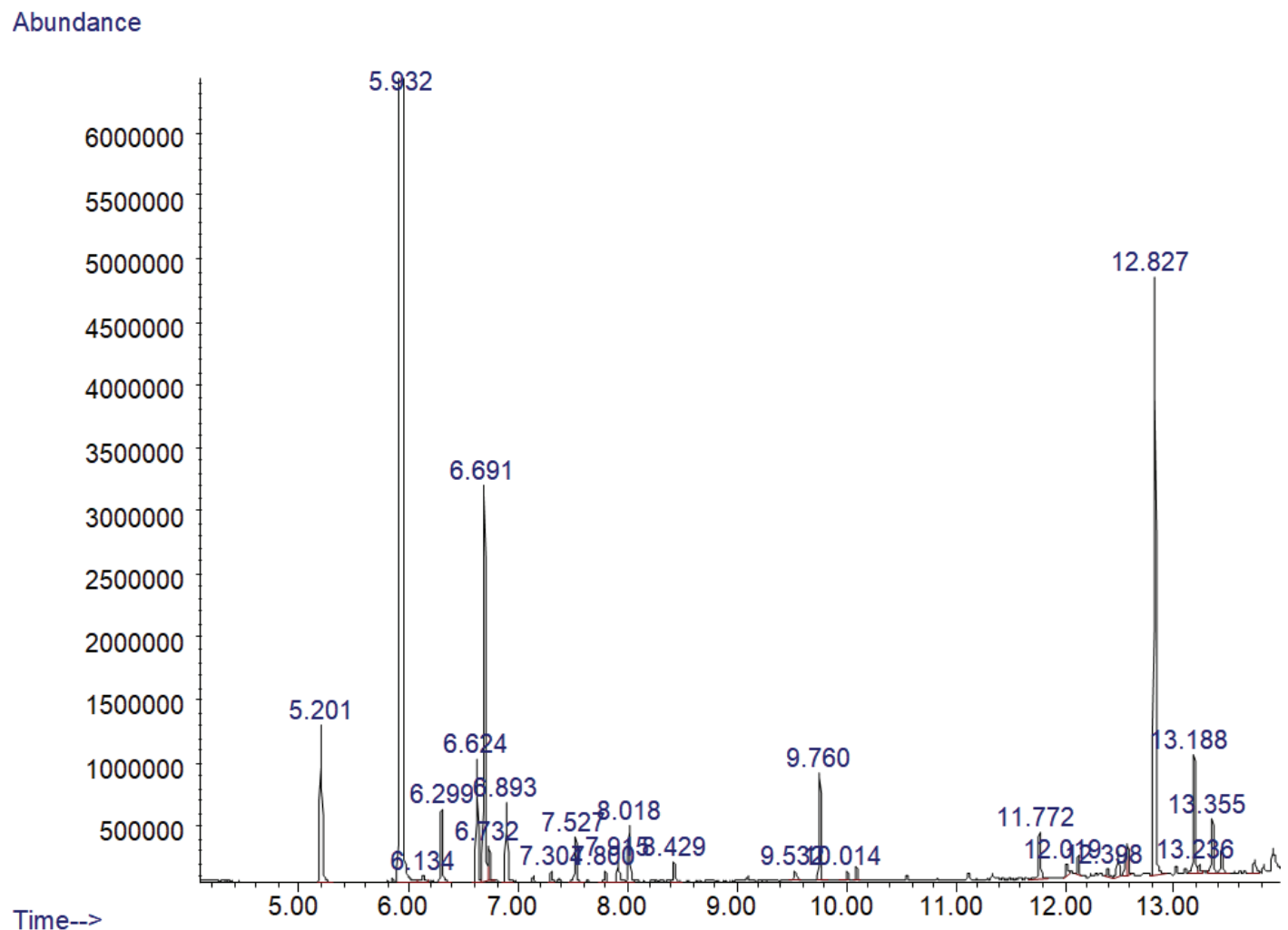

Figure 1. GC/MS of dichloromethane (DCM) extract from a reaction mixture of $\mathrm{CDS}+\mathrm{NH}_{4} \mathrm{OH}$ without any hydrolyzed F1 protein at $120^{\circ} \mathrm{C}$ for $60 \mathrm{~min}$.

Abundance

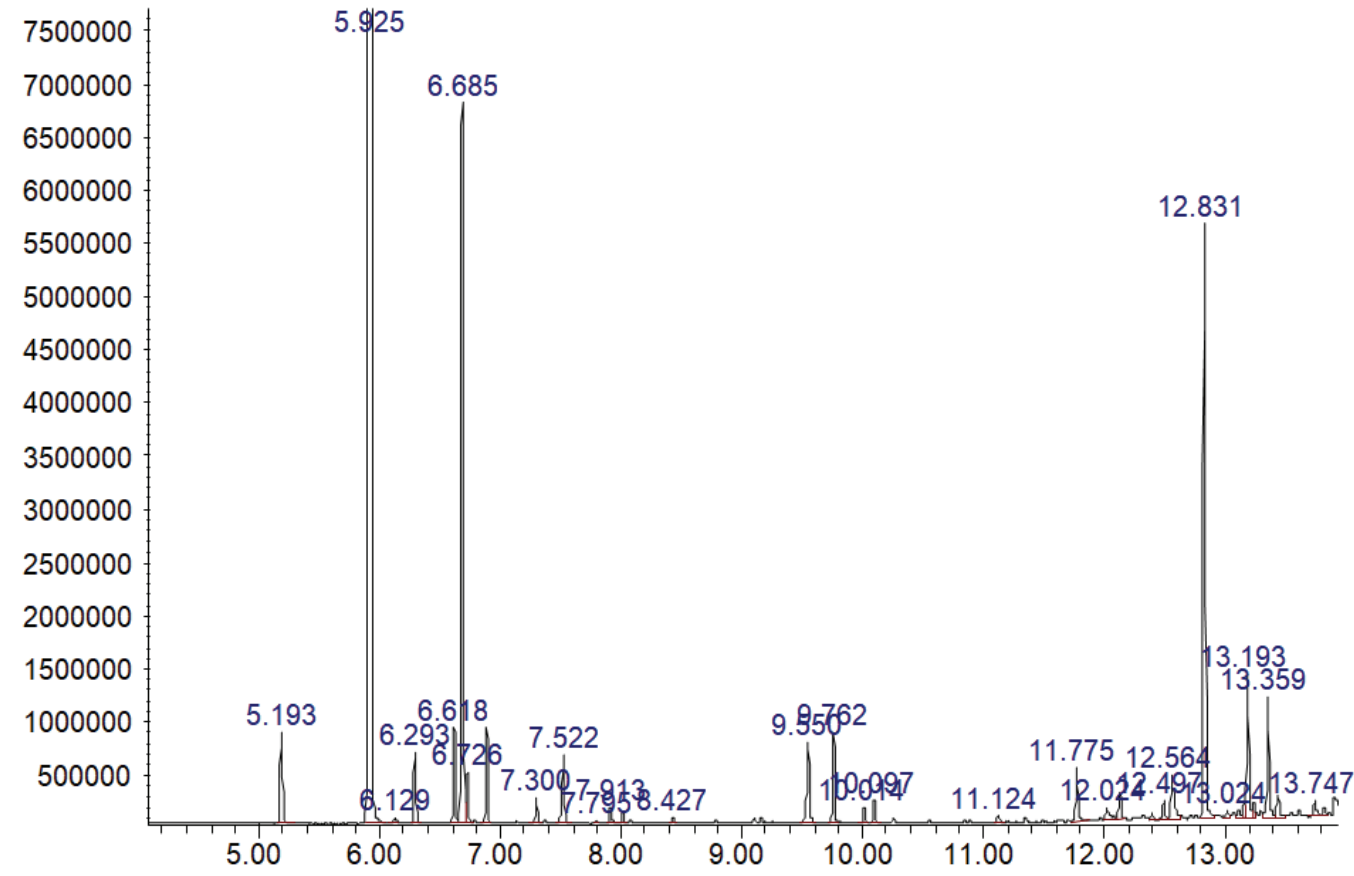

Time-->

Figure 2. GC/MS of DCM extract from a reaction mixture of CDS $(7.7 \mathrm{~g})+\mathrm{NH}_{4} \mathrm{OH}(1.8 \mathrm{~mL})+0.4 \mathrm{~g}$ of AA's from filtered hydrolyzed $\mathrm{F} 1$ protein at $120^{\circ} \mathrm{C}$ for $60 \mathrm{~min}$. See Experimental section for chromatography conditions. 


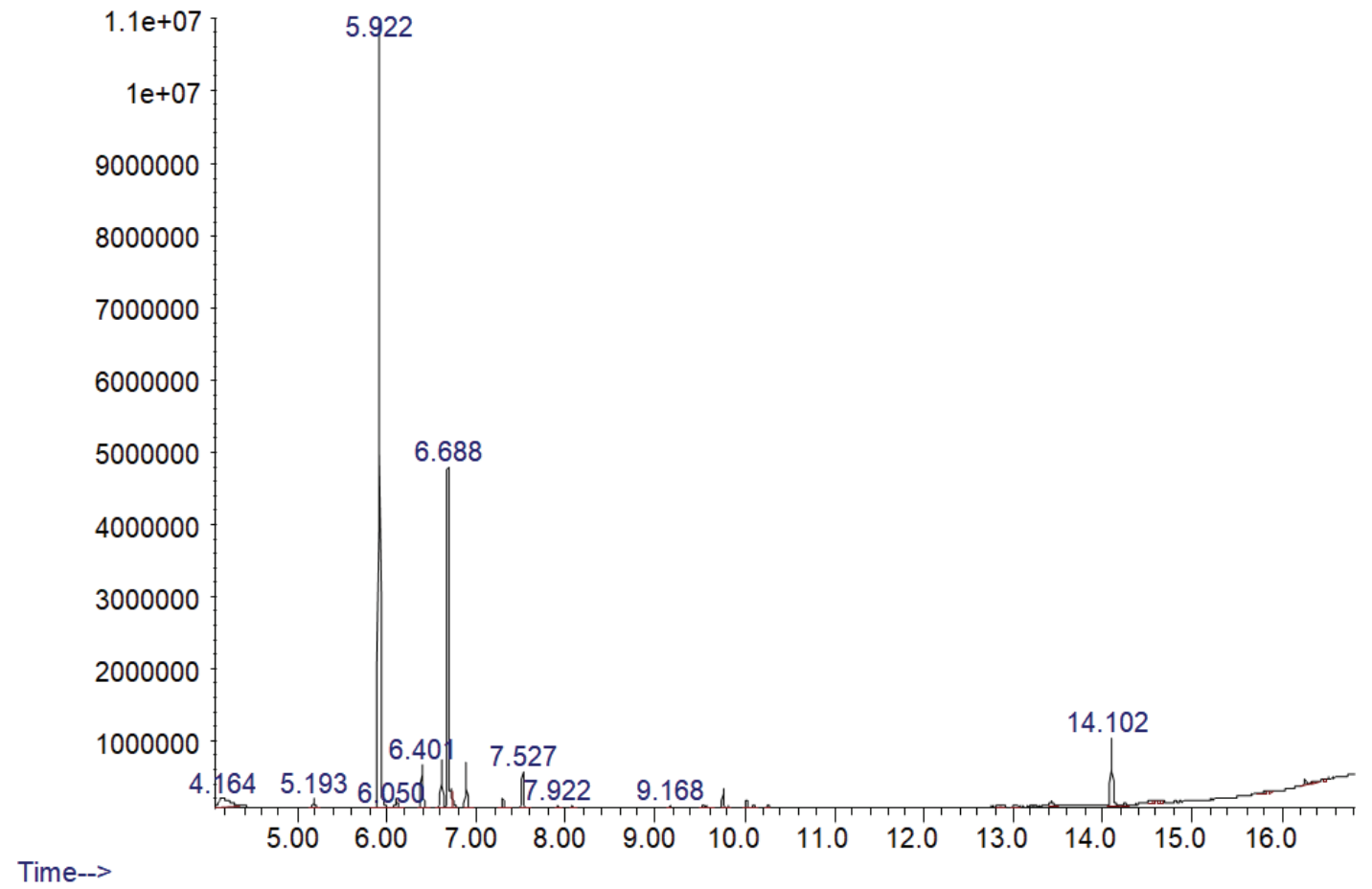

Figure 3. GC/MS of final pyrazines distilled and isolated from reaction of CDS with $\mathrm{NH}_{4} \mathrm{OH}$ and hydrolyzed F1 protein in a Parr vessel at $120^{\circ} \mathrm{C}$ for $60 \mathrm{~min}$ (see Table 4 for list of identified pyrazines).

used instead of filtered hydrolyzed F1 protein, the total mass of pyrazine was about $10 \%$ higher than with the filtered hydrolyzed F1 protein.

\section{Reaction of CDS with and without filtered hydrolyzed F1} protein and isolated amino acids

In this part of the study, similar experiments as above were performed, but instead of HFCS as the sugar source, CDS was used. Reaction conditions were similar to those performed with HFCS. In this study, a constant mass $(7.7 \mathrm{~g})$ of CDS was reacted with a constant volume $(1.8 \mathrm{~mL})$ of $\mathrm{NH}_{4} \mathrm{OH}$, with and without 0.4 gram of $\mathrm{F} 1$ amino acids. The source of amino acids again was hydrolyzed F1 protein whose characteristics have been previously reported (7). Experiments were performed with and without filtered hydrolyzed F1 protein. Also, experiments were performed using $0.4 \mathrm{~g}$ purified amino acids after hydrolysis of F1 protein. In another experiment, the mass of amino acids was doubled to study the effect of additional amino acids on the synthesis of pyrazines. Also, in another experiment additional threonine $(0.4 \mathrm{~g})$ was added to the reaction that contained $\mathrm{CDS}, \mathrm{NH}_{4} \mathrm{OH}$ and $0.4 \mathrm{~g}$ of hydrolyzed F1 protein, see Table 1. This was done to test, if threonine could increase or decrease the mass of certain pyrazines and to test, if the presence of additional threonine would shift the distribution of the pyrazines toward those having three and four carbons attached, see Table 3.

As it was expected, addition of free amino acids caused pyrazines with larger than three carbon atoms (as a side chain) to be synthesized. Using isolated amino acids did not change the mass of pyrazines in the reaction. Also, using filtered or unfiltered hydrolyzed $\mathrm{F} 1$ protein did not change the yield of pyrazines in the reaction. However, it is important to note here that when filtered or isolated amino acids from hydrolyzed F1 protein were used, the resulting reaction solution was much cleaner and less viscous. Addition of extra threonine did not increase the yield of pyrazines, but a slight shift toward the distribution of those pyrazines having three and four carbons attached was observed, see Table 3 . The presence of pyrazines having the 3-methylbutyl substituent strongly implicates the involvement of isoleucine in a Strecker/Maillard reaction pathway. For those reactions employing a reaction temperature of $120^{\circ} \mathrm{C}$, no significant differences were noted between the pyrazine yields when HFCS (fructose + glucose) and CDS (glucose) were employed. Figures 1 and 2 show chromatograms representative of the pyrazine profiles obtained with the smaller scale reactions.

Reaction of CDS with hydrolyzed F1 protein and ammonium hydroxide

In this part of the study, $\mathrm{CDS}$ was reacted with $\mathrm{NH}_{4} \mathrm{OH}$ and optimized hydrolyzed F1 protein (7). The optimized F1 protein mixture was prepared by varying the type and amount of hydrolysis enzymes along with reaction conditions of temperature and time to produce the maximum amounts of free amino acids. In this reaction $323 \mathrm{~g}$ of CDS were mixed with $839 \mathrm{~mL}$ of hydrolyzed $\mathrm{F} 1$ protein and $76 \mathrm{~mL}$ of $\mathrm{NH}_{4} \mathrm{OH}$ (employing the following reagent quantity adjustments: every $20 \mathrm{~mL}$ of hydrolyzed $\mathrm{F} 1$ pro- 
Table 3. Average mass of pyrazines formed from reaction of $\mathrm{CDS}, \mathrm{NH}_{4} \mathrm{OH}$ and amino acids isolated from hydrolyzed $\mathrm{F} 1$ protein and amino acids from filtered and unfiltered hydrolyzed F1 protein.

\begin{tabular}{|c|c|c|c|c|c|c|c|c|}
\hline $\begin{array}{l}\text { Retention } \\
\text { time }\end{array}$ & Experiment conditions & $\begin{array}{l}\text { Quantitative } \\
\text { ion }\end{array}$ & $\begin{array}{c}F^{*} \\
\operatorname{mass}(\mu \mathrm{g})\end{array}$ & $\begin{array}{c}\mathrm{G}^{*} \\
\operatorname{mass}(\mu \mathrm{g})\end{array}$ & $\begin{array}{c}\mathrm{H}^{*} \\
\operatorname{mass}(\mu \mathrm{g})\end{array}$ & $\begin{array}{c}\mathrm{I}^{\star \star} \\
\operatorname{mass}(\mu \mathrm{g})\end{array}$ & $\begin{array}{c}\mathrm{J}^{\star *} \\
\operatorname{mass}(\mu \mathrm{g})\end{array}$ & $\begin{array}{c}\mathrm{K}^{*} \\
\operatorname{mass}(\mu \mathrm{g})\end{array}$ \\
\hline 5.192 & Pyrazine & 80 & & & & & & \\
\hline 5.92 & 2- Methylpyrazine & 94 & & & & & & \\
\hline 5.92 & 2-Methylpyrazine-d 6 (int. standard) & 100 & 250.0 & 250.0 & 250.0 & 250.0 & 250.0 & 250.0 \\
\hline 6.61 & 2,5-Dimethylpyrazine & 108 & 2293.9 & $1534.8(10.7)$ & 1661.2 & $1595.1(20.8)$ & $2024.7(6.1)$ & 926.7 \\
\hline 6.68 & 2,6-Dimethylpyrazine & 108 & 7935.3 & $13745.8(17.5)$ & 11528.1 & $13791.8(14.3)$ & $13493.7(6.6)$ & 8381.7 \\
\hline 6.72 & 2-Ethylpyrazine & 108 & 455.6 & $535.6(22.5)$ & 518.3 & $671.3(17.4)$ & $670.7(7.8)$ & 962.7 \\
\hline 6.88 & 2,3-Dimethylpyrazine & 108 & 1380.9 & $1420.2(3.3)$ & 1379.5 & $1325.6(14.0)$ & $1667.6(5.2)$ & 987.6 \\
\hline 7.29 & 2-Ethyl-6-methylpyrazine & 122 & 118.6 & $212.5(29.9)$ & 187.1 & $351.3(30.7)$ & $246.8(12,9)$ & 491.8 \\
\hline 7.37 & 2-Ethyl-5-methylpyrazine & 122 & 36.4 & $31.1(29.4)$ & 31.0 & $48.8(36.6)$ & 44.9 (13.3) & 49.0 \\
\hline 7.52 & Trimethylpyrazine & 122 & 727.4 & $1023.4(11.2)$ & 970.2 & $1014.4(18.9)$ & $1127.8(6.1)$ & 922.8 \\
\hline 7.79 & 2-Vinylpyrazine & 106 & 179.4 & $71.8(17.5)$ & 98.4 & $59.1(14.8)$ & $104.3(4.0)$ & 46.7 \\
\hline 7.91 & 3-Ethyl-2,5-dimethylpyrazine & 136 & 11.0 & $36.0(21.5)$ & 34.0 & $52.6(27.2)$ & 33.4 (13.3) & 83.2 \\
\hline 8.08 & 5-Ethyl-2,3-dimethylpyrazine & 136 & 15.5 & $41.4(24.8)$ & 38.6 & $56.9(27.3)$ & $43.2(12.5)$ & 95.7 \\
\hline 8.22 & Tetramethylpyrazine & 136 & 18.9 & $20.1(16.7)$ & 21.3 & $21.0(24.5)$ & $24.4(7.0)$ & 16.4 \\
\hline 8.31 & 2-Ethenyl-6-methylpyrazine & 120 & 34.7 & 30.9 (31.9) & 33.8 & $34.8(14.8)$ & $34.8(7.0)$ & 26.6 \\
\hline 8.42 & 2-Butyl-3-methylpyrazine & 108 & 0.0 & $20.3(42.5)$ & 20.3 & $28.3(25.8)$ & $22.5(15.5)$ & 9.0 \\
\hline 9.16 & 3-Methylbutyl pyrazine & 94 & 0.0 & $147.0(35.5)$ & 166.8 & $273.2(24.7)$ & $139.1(15.3)$ & 82.6 \\
\hline \multirow[t]{2}{*}{9.80} & 2,5-Diethyl-3-methylbutyl pyrazine & 122 & 0.0 & $32.5(13.4)$ & 56.4 & $92.1(26.1)$ & $43.0(12.7)$ & 33.0 \\
\hline & Total pyrazine mass $(\mu \mathrm{g})$ & & 13265.2 & 18947.9 (13.5) & 16787.7 & 19492.0 (15.8) & $19791.1(6.5)$ & 13143.3 \\
\hline
\end{tabular}

** Triplicate reaction (\% RSD), * duplicate reactions

F $7.7 \mathrm{~g} \mathrm{CDS}, 1.8 \mathrm{~mL} \mathrm{NH} \mathrm{OH}_{4}$, No AA, $120^{\circ} \mathrm{C}, 60 \mathrm{~min}$

G $7.7 \mathrm{~g} \mathrm{CDS}, 1.8 \mathrm{~mL} \mathrm{NH}_{4} \mathrm{OH}, 20 \mathrm{~mL} \mathrm{~F} 1$ hydrolysate $(0.4 \mathrm{~g} \mathrm{AA}), 120^{\circ} \mathrm{C}, 60 \mathrm{~min}$

$\mathrm{H} \quad 7.7 \mathrm{~g} \mathrm{CDS}, 1.8 \mathrm{~mL} \mathrm{NH}_{4} \mathrm{OH}, 2.5 \mathrm{~mL}$ purified $\mathrm{AA}(0.4 \mathrm{~g} \mathrm{AA}), 120^{\circ} \mathrm{C}, 60 \mathrm{~min}$

I $7.7 \mathrm{~g} \mathrm{CDS}, 1.8 \mathrm{~mL} \mathrm{NH}_{4} \mathrm{OH}, 5 \mathrm{~mL}$ purified $\mathrm{AA}(0.8 \mathrm{~g} \mathrm{AA}), 120^{\circ} \mathrm{C}, 60 \mathrm{~min}$

J $7.7 \mathrm{~g} \mathrm{CDS}, 1.8 \mathrm{~mL} \mathrm{NH}_{4} \mathrm{OH}, 20 \mathrm{~mL}$ unfiltered $\mathrm{F} 1$ hydrolysate $(0.4 \mathrm{~g} \mathrm{AA}), 120^{\circ} \mathrm{C}, 60 \mathrm{~min}$

$\mathrm{K} \quad 7.7 \mathrm{~g} \mathrm{CDS}, 1.8 \mathrm{~mL} \mathrm{NH}_{4} \mathrm{OH}, 20 \mathrm{~mL}$ F1 hydrolysate $(0.4 \mathrm{~g} \mathrm{AA}), 120^{\circ} \mathrm{C}, 60$ min. plus $0.4 \mathrm{~g} \mathrm{THR}$

tein contained $0.4 \mathrm{~g}$ of $\mathrm{F} 1$ amino acids and every $7.7 \mathrm{~g}$ of CDS required $1.8 \mathrm{~mL}$ of $\mathrm{NH}_{4} \mathrm{OH}$ ). The mixture was prepared in a $1.5-\mathrm{L}$ glass container which was housed in a Parr reaction vessel with mixing device and thermometer. The mixture was stirred and heated for 40 min until the temperature of the reaction mixture was stable at $120^{\circ} \mathrm{C}$. After stabilization of the temperature at $120^{\circ} \mathrm{C}$, the mixture was stirred and heated for additional $60 \mathrm{~min}$. These reaction conditions were very similar to reaction $\mathrm{J}$, with a longer overall reaction time being employed. Then the reaction mixture was cooled and transferred into a glass jar container and kept in a refrigerator for later steps which included distillation and isolation of pyrazines.

\section{Distillation of pyrazines from large reaction of $C D S$}

Due to the relatively large volume of the reaction mixture (approximately $1.1 \mathrm{~L}$ ) and a limited-sized distillation apparatus, only $350-400 \mathrm{~mL}$ of the reaction mixture was distilled each time. The mixture was heated to $120^{\circ} \mathrm{C}$ with an oil bath and the distilled material was collected in a clean flask in a manner previously described (10). After collection of approximately $65-75 \mathrm{~mL}$ of distilled solution in a clean flask, an analysis of a dichloromethane (DCM) extract of the reaction mixture confirmed a significant reduction of the amount of pyrazines remaining in the reaction mixture. This process was repeated two more times with the remaining undistilled reaction mixture to isolate all pyrazines. The final volume of all distilled material from
1.1 L reaction mixture, which contained only pyrazines and water, was approximately $200-220 \mathrm{~mL}$ of a colorless solution.

Next, a glass column $(60 \times 5 \mathrm{~cm})$ packed with only $15 \mathrm{~cm}$ (about $85 \mathrm{~g}$ ) of $\mathrm{C}_{18}$ packing (SPE cartridges packing material from Supelco (Bellefonte, PA, USA) was used to isolate the pyrazines, loading $\sim 30-35 \mathrm{~mL}$ of distillate per separation. No optimization was performed on how much of the distilled solution could be loaded onto the column before overloading it. The only test to show that the column was not overloaded, was to make sure that any distillate eluting from the column did not contain any pyrazines. This test was carried out by a simple DCM extraction of eluted $\mathrm{H}_{2} \mathrm{O}$ from the column followed by analysis via GC/MS.

Before loading the column with the distillated solution, the column was conditioned first by washing with $150-200 \mathrm{~mL}$ of methanol $(\mathrm{MeOH})$ through the column, followed by washing with $150-200 \mathrm{~mL}$ of $0.1 \%$ formic acid solution and finally washing it with $100 \mathrm{~mL}$ of deionized $\mathrm{H}_{2} \mathrm{O}$. After the water was eluted from the column without letting the column go dry, $30-35 \mathrm{~mL}$ of distilled solution was loaded onto the column and allowed to drain at a flow rate of 3-5 $\mathrm{mL} / \mathrm{min}$. Afterwards the column was washed with an additional $75-100 \mathrm{~mL}$ of deionized $\mathrm{H}_{2} \mathrm{O}$. At this point all eluted water from the column was collected and the solution was analyzed indicating no detectable pyrazines. After complete elution of $\mathrm{H}_{2} \mathrm{O}$ from the column, it was dried for 5-10 min by passing $\mathrm{N}_{2}$ through it. Finally, all 
trapped pyrazines were eluted with ethanol or methanol. Due to lower polarity of ethanol, a larger volume (135-150 $\mathrm{mL})$ of ethanol was required compared to methanol (100-120 mL) to elute the pyrazines from the $\mathrm{C}_{18}$ column. Figure 3 illustrates the GC/MS of the isolated pyrazines that were distilled from the reaction of CDS with $\mathrm{NH}_{4} \mathrm{OH}$ and hydrolyzed $\mathrm{F} 1$ protein at $120{ }^{\circ} \mathrm{C}$ in a Parr vessel for $60 \mathrm{~min}$, afterwards they were isolated and then eluted from the $\mathrm{C}_{18}$ column. Table 3 shows list of identified pyrazines in Figure 3 and their retention times. It is important to note that even though their presence is not clearly indicated by Figure 3, all of the pyrazines noted in Table 4 were positively identified in the isolate. When qualitatively comparing the array of pyrazines produced by employing the small reaction volume with the array obtained by employing the relatively large reaction volume, differences could be detected.

Table 4. List of identified pyrazines in Figure 3.

\begin{tabular}{c|l|c}
\hline $\begin{array}{c}\text { Retention } \\
\text { time }\end{array}$ & \multicolumn{1}{c}{ Compound } & Quantitative ion \\
\hline 5.193 & Pyrazine & 80 \\
5.922 & Methylpyrazine, + int. standard & 94,100 \\
6.620 & 2,5-Dimethylpyrazine & 108 \\
6.688 & 2,6-Dimethylpyrazine & 108 \\
6.726 & Ethylpyrazine & 108 \\
6.890 & 2,3-Dimethylpyrazine & 108 \\
7.304 & 2-Ethyl-6-methylpyrazine & 122 \\
7.369 & 2-Ethyl-5-methylpyrazine & 122 \\
7.527 & Trimethylpyrazine & 122 \\
7.924 & 3-Ethyl-2,5-dimethylpyrazine & 136 \\
8.084 & 2,3-Dimethyl-5-ethylpyrazine & 136 \\
8.220 & Tetramethylpyrazine & 136 \\
9.169 & 2-Pentylpyrazine & 94 \\
9.580 & 2-Isopentyl-3-methylpyrazine & 108 \\
9.816 & 2,5-Dimethyl-3-isoamylpyrazine & 122 \\
10.104 & 1-(6-Methyl-2-pyrazinyl)-1-ethanon & 122 \\
\hline
\end{tabular}

Specifically, the last four pyrazines listed in Table 4 (large reaction volume) fail to appear anywhere in the list of pyrazines found stemming from all the smaller reaction volume reactions. A possible reason for this discontinuity in qualitative arrays could rest with the sample preparation approaches which were very different. For all of the small volume reactions, DCM extraction of the reaction mixture was employed to determine the pyrazine array. For the relatively large reaction volume, the pyrazines were first steam-distilled from the reaction mixture and the clear colorless aqueous distillate was extracted with DCM. It could be speculated that differences in steam volatility precipitated a difference in the pyrazine array, that is, some of the pyrazines present in the larger reaction volume might not be significantly volatile with steam, yet readily extractable with DCM. Steam distillation is a convenient method for segregating the desirable pyrazines away from less than desirable side reaction compounds, contained within the reaction mixture.

\section{CONCLUSIONS}

The results of this investigation demonstrated that the addition of enzymatically hydrolyzed tobacco $\mathrm{F} 1$ protein as a source of free amino acids could increase the yield of pyrazines with more than three carbons attached to the pyrazine ring compared to the pyrazine yields when no free amino acids were employed. This is consistent with well known amino acid Maillard and Amadori chemistry. Also, it was shown that use of isolated amino acids from enzymatically hydrolyzed tobacco $\mathrm{F} 1$ protein as the amino acid source did not result in increased yields or increased types of pyrazines synthesized when compared with the results obtained when the hydrolysis reaction mixture was employed. Also, there was no difference in yields or type of pyrazines whether filtered or unfiltered hydrolyzed F1 protein was used in the reaction mixture. Addition of threonine did not increase yields or type of pyrazines in the synthesis but it did slightly shift the pyrazine distribution toward those with three and four carbons attached. After distillation of the pyrazines from a relatively large 1 L-reaction, followed by isolation of the pyrazines using column chromatography packed with $\mathrm{C}_{18}$, pyrazines having alkyl groups numbering between two and five carbons were produced. Thus, free amino acids generated by enzymatic hydrolysis of tobacco F1 protein and sugar (glucose) from tobacco cellulose can serve as nitrogen and carbon sources, respectively, for the synthesis of a unique array of pyrazines, known for their positive sensory attributes. The sugar (glucose) derived from tobacco was as effective as HFCS in the production of pyrazines, resulting in a qualitatively similar array of pyrazines as well. A reaction temperature of $100{ }^{\circ} \mathrm{C}$ produced approximately $50 \%$ less pyrazines when compared with to a reaction temperature of $120^{\circ} \mathrm{C}$.

\section{REFERENCES}

1. Ellis, G.P.: The Maillard Reaction; Adv. Carbohydr. Chem. 14 (1959) 63-134.

2. Weenen, W., S.B. Tjan, P.J. de Valios, N. Bouter, A. Pos, and H. Vonk: Mechanism of Pyrazine Formation; ACS Symposium Series, in Thermally Generated Flavor, American Chemical Society, Washington, DC, USA, 1994, Chapter 12, pp 142-157.

DOI: $10.1021 / \mathrm{bk}-1994-0543 . c h 012$

3. Coleman, W.M.: On the Synthesis and Characteristics of Aqueous Formulations Rich in Pyrazines; in Flavor, Fragrance, and Odor Analysis, edited by R. Marsili, CRC Press, Boca Raton, FL, USA, 2012, pp. 135-181.

4. Shibamoto, T. and R.A. Bernhard: Effect of Time, Temperature, and Reactant Ratio on Pyrazine Formation in Model Systems; J. Agric. Food Chem. 24 (1976) 847-852. DOI: 10.1021/jf60206a045

5. Ara, K.M., L.T. Taylor, M. Ashraf-Khorassani, and W.M. Coleman III: Alkyl Pyrazine Synthesis via an Open Heated Bath with Variable Sugars, Ammonia, and Amino Acids; J. Sci. Food Agric. 97 (2017) 2263-2276. DOI: 10.1002/jsfa.8039

6. Ara, K.M., L.T. Taylor, and W.M. Coleman III: Conversion of Tobacco Biomass to Flavor Components by Means of Microwave and Parr Reactors; Beitr. 
Tabakforsch. Int. 27 (2017) 102-112.

DOI: $10.1515 / \mathrm{cttr}-2017-0011$

7. Ashraf-Khorassani, M., W.M. Coleman III, M.F. Dube, and L.T. Taylor: Isolation of Free Amino Acids Produced by the Optimized Enzymatic Hydrolysis of Tobacco-Derived F1 Protein; Beitr. Tabakforsch. Int. Submitted for Publication, 2018.

8. Fors, S.M. and B.K. Olofsson: Alkylpyrazines, Volatiles from the Maillard Reaction. II. Sensory Properties of Five Alkylpyrazines; Chem. Senses 11 (1986) 65-77. DOI: 10.1093/chemse/11.1.65

9. Fors, S.: Sensory Properties of Volatile Maillard Reaction Products and Related Compounds; in The Maillard Reaction in Foods and Nutrition, edited by G.R. Waller and M.S. Feather, ACS Symposium Series, Washington DC, Volume 215, pp. 185-286. DOI: 10.1021/bk-1983-0215.ch012

10. Coleman, W.M. and A.R. Gerardi: Method of Preparing Flavorful and Aromatic Compounds; US Patent Application 2010037903 (2010).

Corresponding author:

Mehdi Ashraf-Khorassani

Department of Chemistry

Virginia Tech

Blacksburg, VA 24061, USA

E-mail: mashraf@vt.edu 